\title{
Forum
}

\section{"Unless we have some kind of United States of Europe, I do not think we can hope for proper economic policies." \\ Interview with Philip Arestis*,**}

You are looking back on more than 40 years of academic life and you will enter your $70^{\text {th }}$ year of life this year. What was your motivation

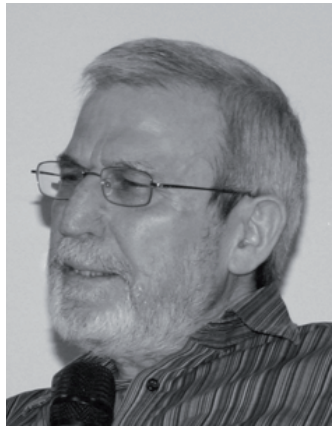
to become an economist and what were the major steps in your career as a professional economist?

I was born in Cyprus and my father always used to take me, as a very young man, with him to the bank to withdraw or deposit money, or whatever. At that early stage, I was very curious about how these banks made their money. Indeed, how is it that they are allowed to use my money to make their money? That became a very interesting question at the back of my mind, and finally I decided that I should do economics. First, I went to the Athens Graduate School of Economics and Business Studies. There I specialized in economics and I began to understand a little bit more of why is it that the banks use your money, and know how to make more money and huge profits. But the economics in Athens did not quite satisfy me. I very much wished to go to the London School of Economics (LSE) to do further economics. Cyprus at that time was part of the British Empire. So I had already been exposed to British institutions and more generally speaking I knew a great deal about Britain and of course about the academic institutions and universities in particular. So I did not hesitate to move over to London and study for a postgraduate course at the LSE. I decided that London was where I wanted to spend the rest of my life. And to this day, I seemed to have managed it.

When I finished my MSc at the LSE I got a job at what was then Woolwich Polytechnic in London, which now has become Greenwich University. But at the same time, I was teaching at Surrey University and also at the University of Cambridge. I had close friends at the University of Surrey, so I decided to finish my PhD there, which was in the mid-seventies. I became a Senior Lecturer there, at what is now Greenwich University, and later on a Principal Lecturer and Head of the Division of Economics. We created there the Thames

* Philip Arestis is Professor of Economics, Department of Applied Economics V, University of the Basque Country, Spain; and Honorary Senior Departmental Fellow, Cambridge Centre for Economic and Public Policy (CCEPP), Department of Land Economics, University of Cambridge, UK. He has published widely in academic journals, published as single or joint author, as well as co-edited more than 60 books, and has served on the editorial board of a number of journals.

** We would like to thank Sebastian Türk for the transcription of the interview.

(C) INTERVENTION 7 (2), 20IO, 23I-236 
Papers in Political Economy, which subsequently became International Papers in Political Economy, the journal that Malcolm Sawyer and I still edit to this day.

I then moved to the University of East London as Head of the Department of Economics, before moving to other places, including the Levy Economics Institute at Bard College in the USA for a couple of years. When I returned to the UK I joined the Department of Land Economy at the University of Cambridge where I am at the moment, and where we created the Cambridge Centre for Economic and Public Policy.

\section{How did you get in contact with post-Keynesian economics?}

I was at the LSE in the late I960s. The LSE was a very different academic institution at that time. There were a lot of non-neoclassical economists. People did not teach it but the fashion nonetheless was that you know you have to start asking questions about economics and thinking about alternatives. This was my initial exposure to heterodox economics. At Greenwich University, we created a BA in Political Economy including of course a great deal of Keynesian economics. In our attempt to develop the notion of political economy, we came in touch - and I say swe because we were a group doing this work - with Alfred Eichner. He was at that time heavily involved with post-Keynesian economics. I wanted to find out more about these ideas, so I organized a conference, which Alfred Eichner attended as a keynote speaker. Afterwards, we collaborated very closely. Not only did we collaborate in the sense of he would visit us and some of us would visit him, but we started thinking very seriously along the following lines: could we not have a macroeconomic model, which describes theoretically what post-Keynesian economics might be? Moreover, could we also estimate this model? Let me add at this point that I also invited Malcolm Sawyer to that conference. I had met Malcolm Sawyer at the LSE. I think we were doing the Masters Degree at the same time but I am not quite sure if we ever said "Hello" to each other as students. We became extremely close friends, starting with that particular event, the conference on post-Keynesian economics. The collaboration with Alfred Eichner led to a fully-developed macroeconomic model along post-Keynesian lines, which was fully estimated using UK data. Unfortunately, Alfred Eichner died very prematurely and before we finished the project - I was very saddened indeed, I must say, but determined to finish the work in his memory as well as on intellectual grounds. A great deal of publications ensued. Some aspects of that work continued to be developed, especially so in collaboration with Malcolm Sawyer.

In the Ig6os and I970s it looked as if post-Keynesian economics had a potential to replace neoclassical economics as the mainstream. From the perspective of today, why did it not succeed in doing so?

I do not agree that the I960s and I970s were a period where anybody seriously was thinking that post-Keynesian economics would replace neoclassical economics. At that time the post-Keynesian paradigm had just begun to develop. Paul Davidson and Sidney Weintraub started the Journal of Post Keynesian Economics during that period. Of course, we had the collapse of the Grand Neoclassical Synthesis. But in the early I970s the development of the rational expectations hypothesis emerged, which was very convenient for the orthodox economists to take advantage of and develope it; and that was precisely what happened. 
We had the development of the so called New Classical economics and then in response to that we had the New Keynesian economics followed by the New Consensus as it is known today. So that when the post-Keynesian paradigm with all the developments and contributions from Cambridge and elsewhere in the UK, from America and Australia, and from Europe, matured, it was a little too late for it to replace any of the developments to which we have just referred.

We undertook a number of initiatives. We started developing a macroeconomic model with Alfred Eichner after the conference mentioned above. We applied with Victoria Chick to the Economic and Social Research Council that is the funding council in the United Kingdom, and managed to acquire funding, which enabled us to start the Post-Keynesian Economics Study Group, which is still active. The early stages of this study group were extremely successful. It was very well attended and we had people from all over the world to contribute but more recently it lost a little bit of the initial impetus. Why did it loose its initial impetus is very difficult to say, but the development of the New Consensus around the same time may explain it to some extent.

I think the one problem with post-Keynesians is that they have shied away from the developments in the discipline of economics, for example in the case of applied econometrics. I think it is a mistake because if you shy away, then the wider community of economists will tend to ignore you, and we may have suffered as a result of that. From my point of view I have not given up the approach I have always been concerned with, which is working with the focus on the theory of the problem in hand. But I am very concerned at the same time to look at the real world where testing of hypotheses against data is very important. I am still doing it to this day.

Nowadays, you were among the very early critics of the New Consensus Model and obviously this model has failed in the present crisis. Will the New Consensus Model be replaced? Or will it be amended in one way or the other, but without touching its core?

You are absolutely right, and you know there have been problems with the New Consensus macroeconomics, and therefore that in itself would suggest that either it has to be completely replaced by something else, or changed to some extent. In my view, I do not see a desire by the proponents to accept the major problems to the extent that they will be persuaded to replace it with something else. But that does not mean that there might not be any changes. For example, the existing paradigm emphasizes price stability at the expense of other objectives. If there is a problem with price stability, you keep price stability, from their point of view, but also you introduce other objectives, e.g. to look at economic activity. If one were concerned with the Taylor Rule, which the central banks use in their formulation and implementation of monetary policy, the output gap could be given more importance. Therefore, my argument is that maybe people might begin to redefine slightly the way and the emphasis they give to the variables that determine the change in the rate of interest. This is just one example of possible changes; clearly there are many other ones to which I could refer. 
However, if the situation deteriorates, things of course could very well change. PostKeynesians should try to demonstrate that they have a better model to account for the economic problems and for economic policies, one that is much more satisfactory than the New Consensus paradigm. Let us hope that we can finally persuade the majority of the profession that this approach to economics is worth paying attention to both in terms of its theory and economic policy.

Let us assume this is successful, and a more or less post-Keynesian policy programme would come into force. What key elements in your view would be part of this policy programme, especially against the background of the crisis of the financial system?

In the work we did with Alfred Eichner and the work that Malcolm Sawyer and I have been doing over the years, there is emphasis on economic activity, and consequently we emphasize aggregate demand and the objective of achieving full employment, without at the same time forgetting distributional effects. That means in our view that to do that properly, you have to have a good way of modelling your financial sector, and more importantly linking the financial sector with your real sector properly. Therefore, you have to account for the banks, you have to take into account that there is money, that there are interest rates, that there is liquidity preference, that there is risk in the system, and of course you have to link all those aspects with the foreign sector. This is the kind of model that we are trying to develop. The policy implications we would strongly support are that fiscal policy should be given its proper place, not being downgraded as it has been over the recent past by the New Consensus theoretical framework; without forgetting monetary policy at the same time. So in our view there has to be coordination of monetary and fiscal policy to achieve the objective of full employment. In this coordination, of course, there has to be some role for the central banks. We argue that the role that we should give to the central banks is financial stability. That is where regulatory arrangements become extremely important. We would suggest that the right rate of interest would be the one that corresponds to the growth rate of the economy. That leaves still sufficient room for controlling inflation and the exchange rate. In terms of the exchange rate at the moment we are of the view that it has to be regulated; there has to be intervention in the foreign exchange market by the monetary authorities. As for inflation, there is no urgent need to do much about provided that inflation is within certain limits. The problem begins when inflation starts rising beyond single figures. In those circumstances we would suggest that incomes policies become relevant. We would also recommend industrial policies to enhance the supply side of the economy and keep it in tune with aggregate demand.

Fiscal policy plays a prominent role in your approach. You are advocating it by following the Functional Finance approach originated by Abba Lerner. Does this approach not include a problem of public debt?

From the point of view of the New Consensus, the reason why fiscal policy is downgraded so significantly is the belief in the Ricardian equivalence theorem which leads to crowding out. The Ricardian equivalence theorem presupposes that agents are very rational. They know 
exactly how the economy works and can predict the implications of shocks to the economy. Therefore when the government increases the deficit, say, then rational economic agents know that the government has to increase taxes in the future, and therefore increase their savings today. The ensuing reduction of private expenditures crowds out the increased government expenditure. Fiscal policy, therefore, is impotent in terms of stimulating economic activity.

My work on this issue over the years has shown that there is no such crowding out. The work of other colleagues has also shown that fiscal policy could indeed be very effective. Functional finance means that you use deficits as required. But at the end of the line, the problems with debt are not very serious, because once you begin to successfully cure the problem in hand, then of course there would be increases in taxes in view of higher economic activity. Also in our approach we suggest that the debt issue that certain people are so worried about is not such a big issue. We know that there have been countries around the globe, for example Japan, that have had very high debt in relation to GDP, and there does not seem to have been so serious problems. So why put so much emphasis on these ratios in order to demise fiscal policy? Consequently, in our approach we still maintain that fiscal policy for these reasons is very important. Consequently, we downgrade the dangers that people talk about in terms of high debt to GDP and high deficits. Nevertheless, we are not suggesting that we should go on building debts and deficits ad infinitum.

\section{What are the implications of your policy programme for the European Monetary Union?}

The current European institutions do not help in terms of proper coordination of monetary and fiscal policy. The European Central Bank has the only pan-EMU policy, which is monetary policy, and it is manipulating the rate of interest with an eye to euro area inflation only. We know that this in itself is problematic. The ECB rate of interest might be in normal cases - not now - suitable for Germany, say, but it might not be so adequate for other countries. The Stability and Growth Pact in our view is unacceptable in the sense that we were never able to understand what these numbers mean - why 3 per cent of GDP deficit and not another number? Where do these numbers come from? The idea that over the cycle you should always try to have a budget surplus rather than a deficit is not a very sensible macroeconomic principle.

The way that monetary and fiscal policies are operated is very much within the New Consensus. The arguments we used against the New Consensus can easily be applied in the case of the institutional setup in Europe, too. Political integration along with further economic integration is necessary, which we do not have presently. In other words, unless we have some kind of United States of Europe, I do not think we can hope for proper economic policies of the type we and others have been suggesting.

The interview was conducted by Eckhard Hein and Torsten Niechoj in August 2009.

\section{Selected Publications of Philip Arestis}

Introducing Macroeconomic Modelling: An Econometric Study of the United Kingdom (Macmillan, 1982) - The Post-Keynesian Approach to Economics (Edward Elgar, 1992) - Money, Pricing 
Distribution and Economic Integration (Macmillan, 1997) • The Euro: Evolution and Prospects (Edward Elgar, 200I) • Re-Examining Monetary and Fiscal Policies in the Twenty First Century (Edward Elgar, 2004) • The Post-Bubble US Economy: Implications for Financial Markets and the Economy (Palgrave Macmillan, 2004) - Is There a New Consensus in Macroeconomics? (Palgrave Macmillan, 2007) - Path Dependency and Macroeconomics (Palgrave Macmillan, 2009) - The Post, Great Recession, US Economy: Implications for Financial Markets and the Economy (Palgrave Macmillan, 20IO) $\bullet 2 I^{\text {st }}$ Century Keynesianism (Palgrave Macmillan, 20IO).

\section{Obituary for Jörg Huffschmid John Grabl*}

The death of Jörg Huffschmid in December 2009, at the age of 69, is a loss to critical economics and to the movement for a more just and rational economic system. Jörg worked, in Germany and in Europe as a whole, both to develop a powerful critique of orthodox economic policies and to make that critique an effective instrument for the labour movement and the movements for environmental protection and sustainable development. ${ }^{\text {I }}$ This required an unusual combination of qualities: scholarship and keen analysis; the ability to persuade and convince in debate; the warmth and generosity which encouraged commitment to joint projects. Jörg was able to emphasize broad shared objectives even among those with intellectual and political differences.

Friends, colleagues, fellow activists across many movements and several generations of his students regarded Jörg with both affection and respect. A memorial conference in Berlin in January 2oro brought together several hundred people to acknowledge their debts to Jörg and to discuss next steps in the various movements to which he contributed.

I got to know Jörg in the context of the EuroMemorandum Group which was set up, largely on his initiative, in the mid I990s. He was not someone who talked a lot about his past and so many of the following details are taken from German friends and the notices which appeared in the German press. ${ }^{2}$

One of Jörg's first academic appointments was, ironically, under the leading economic liberal Helmut Arndt, who directed an Institute for the Research into Economic Concentration at the Free University of Berlin. In spite of his demanding duties as a research assistant, Jörg completed his first book, Die Politik des Kapitals, which would shortly become very important for the student movement in Germany. It had the aim of

I For a list of Jörg's publications, see http://www-user.uni-bremen.de/-huffschm/.

2 See the collection of articles devoted to Jörg in Sozialismus, issue I, 20 Io.

* Middlesex University, London.

(C) INTERVENTION 7 (I), 20IO, 236-24I 